\title{
Problemas psicológicos encontrados em crianças que vivem em contato constante com a violência: um depoimento
}

Yvonne Bezerra de Mello

Introdução: A estrutura do caos

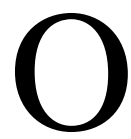

s treze anos de trabalho com crianças e jovens excluídos nas ruas do Rio de Janeiro, obrigaram-me a aprofundar os estudos de filosofia e a mergulhar numa área que me era desconhecida: a psicologia. Com o passar dos anos, eu fui me aprofundando, lendo livros e catalogando os casos que me pareceram mais interessantes. Ao mesmo tempo, desenvolvia métodos de trabalho que me permitissem compreender e aceitar a realidade destas crianças e jovens. Esta não foi uma tarefa fácil. Percebi, desde cedo, que os estudos de Freud e Lacan poderiam me ajudar, mas seriam insuficientes devido ao grau de deterioração daqueles pequenos indivíduos com grandes problemas.

Antes de começar atender a uma criança ou a um jovem, tive de estudar os problemas brasileiros, sociais e políticos, para poder sempre oferecer uma solução no fim de qualquer trabalho com eles. Isto é muito importante para não ficarmos 
na retórica ou dominados por estereótipos que, para nós, burgueses, aparecem a todo o instante. Ficou bem claro na minha mente que não podemos exigir que se comportem como nós, ou que tenham os nossos objetivos. Temos, com certeza, de servir de modelo a nível pessoal, não a nível do coletivo.

Depois de cinco ou seis horas de trabalho nas ruas, vamos para nossas casas, e os deixamos entregues à sua própria sorte, com os mesmos problemas que tinham antes de nós chegarmos. O nosso quotidiano muda, o deles não. Construir este indivíduo quebrado, quer ele tenha cinco anos ou dezoito, será fruto de muita paciência e de um amor imenso. Este amor tem de existir dentro de nós antes de começar qualquer trabalho com eles. O trabalho com crianças e jovens excluídos é de abnegação.

A minha preocupação é com a deterioração dos padrões de comportamento dos brasileiros nas classe altas, e que vai repercutir como um boomerang nas mais baixas. Nós não temos um projeto ou uma orientação de conduta ética, levando as nossas instituições a serem desvirtuadas e não corresponderem aos objetivos para que foram criadas. Neste estado de coisas, os grupos sociais se deterioram, agrupandose em guetos e tendo cada um sua realidade. Tornamo-nos uma sociedade do medo e aceitamos o banditismo social das classes dominantes. Os jovens de baixa renda vivenciam esta situação e, sem saber explicá-la, agrupam-se, desafiando a sociedade que os renega em todos os planos.

Se nós não temos padrões éticos, como passá-los para um segmento que não tem orientação de espécie alguma? A situação de milhões de crianças é desesperadora. Uma grande parte delas, entre 10 e 14 anos, trabalha para se sustentar ou ajudar a família, colocando-nos como terceiro colocado no ranking latino-americano de utilização da mão de obra infantil, atrás apenas do Haiti e da República Dominicana. O caso do Brasil não seria difícil de solucionar se soubéssemos alocar nossos recursos em vez de desperdiçar dinheiro com corrupção e más gestões.

Hoje em dia no nosso país, uma nova geração nasce a cada 12, 13 ou 15 anos. A quantidade de partos de adolescen- 
tes cresce geometricamente a cada ano, mostrando que nossas crianças têm uma vida sexual muito precoce, com danos irreparáveis para a sua vida futura. A maioria das 4 milhões de crianças que nascem no Brasil todos os anos vai passar por dificuldades. Como vamos enfrentar investimentos desta ordem na área da educação e da saúde? Neste ensaio, vou me preocupar mais com as cabeças destas crianças, suas vivências, suas carências e que tipo de juventude ou de vida adulta vão ter. Tudo isto é baseado num trabalho difícil, na maioria das vezes incompreendido pela classe média e alta.

A estrutura do caos que construímos tirou a nossa cordialidade, tornou-nos infinitamente mais vulneráveis, medrosos e invertendo valores. Os ricos protegem-se com grades pensando que, assim, estarão à salvo; os pobres vivem entre as balas da polícia e dos bandidos que entre eles proliferam. É nesta sociedade injusta que crianças ricas e pobres são criadas, e o abismo que as separa torna-se cada dia maior. Este pequeno ensaio será dividido em três partes. Na primeira, abordaremos a violência urbana e suas consequiências diretas no desenvolvimento infanto-juvenil. Na segunda, as crianças já fora do seu habitat de nascimento e já na rua. Na terceira, falarei de casos concretos das crianças na favela e na rua.

\section{Violência nas favelas}

Antes de ser uma criança na rua, ela vem de algum lugar. Normalmente, das favelas dos subúrbios e periferias. O Rio de Janeiro tem uma situação geográfica que permitiu a ocupação dos morros por comunidades de renda muito baixa. Ao mesmo tempo, as favelas proliferaram por toda a cidade e a cidade urbanizada não cresceu no mesmo ritmo. Isto fez com que morro e asfalto convivessem um ao lado do outro. Numa sociedade consumista como a nossa, é inevitável que o conflito aconteça entre os dois lados da cidade partida. A criança pobre carioca convive com um clima de violência constante desde muito cedo. Esta violência tem se intensificado nos últimos dez anos, quando o narcotráfico instalou-se definitivamente no Brasil. Encontrou um terreno muito favorável e proliferou dentro da nossa "estrutura do caos". As favelas 
foram escolhidas como o local ideal para os traficantes devido ao difícil acesso por parte da polícia. As populações vivem numa neo-escravidão, e seu ir e vir depende da vontade dos chefes locais. A mesmo tempo, os núcleos familiares se desintegraram. A grande maioria da população de favelados muito pobres é constituída de mulheres sozinhas com filhos de vários companheiros. A presença do homem só se faz na cama para gerar outros filhos, mas ele não é partícipe ativo na família. Culturalmente, as mulheres brasileiras ainda se submetem à vontade do macho, apanham muito e quase nunca se rebelam, dando ao homem um lugar que ele não merece ter. Aqui, o que vou dizer pode chocar, mas numa pesquisa que eu fiz recentemente, muitas mulheres preferiam apanhar do que ficar sem um companheiro sexual. Este quadro é agravado pelo aumento geométrico no país da maternidade precoce: um milhão de partos de adolescentes (11 a 18 anos) no Brasil em 1996. Estas meninas nunca têm o suporte do pai da criança e engordam as fileiras dos indigentes.

Não existe um só dia em que não se tropece num morto, na maioria das vezes, um adolescente. As crianças pulam por cima dos cadáveres fazendo brincadeiras, cospem e debocham: quão otário ele foi que se deixou abater pela polícia ou pelo traficante. A morte foi totalmente banalizada e, a tal ponto, que jogar futebol com um braço ou uma cabeça, não assusta ninguém. Os adolescentes de 17 anos são, hoje em dia, os donos das bocas de fumo. Morrem cedo, mas nem por isto deixam de ser admirados por uma boa parte das crianças destas comunidades. Crianças essas que nunca saem daquele ambiente e são totalmente desinformadas e desestimuladas. Como a maior parte delas não freqüenta escola, sua vida resume-se na favela ou na comunidade. Nunca fazem um passeio, a não ser que exista algum projeto que se encarregue desta parte. Mas, nas favelas muito violentas, os projetos são poucos. Vou exemplificar melhor. No Natal do ano passado, levei 100 crianças ao cinema para ver O Rei Leão. Depois do cinema, fomos lanchar. Tudo correu bem durante o filme. Quando chegamos ao "MacDonald", não quiseram sair do ônibus. A decisão foi unânime. Diante disso, coloquei os lan- 
ches nas embalagens para viagem e fomos lanchar debaixo do viaduto no centro da cidade. Não quiseram entrar porque sentiram vergonha de não estarem bem vestidos e calçados, e tiveram medo de alguém olhar e debochar. Eu tive muita pena e meu coração ficou muito pequeno. Eles tinham consciência de sua condição de excluídos, da sua pobreza, e acho que tiveram medo de enfrentar um mundo que só conheciam de fora, pedindo esmolas ou migalhas àqueles que se locupletavam lá dentro. Sua condição de escravos ainda estava muito presente, daquilo que é proibido para eles ou daquilo que nós convencionamos proibir. Esta neo-escravidão também aparece quando um adulto consegue qualquer emprego de salário mínimo. Ao invés de comprar os gêneros necessários para a sua família, gasta o dinheiro em roupas de marca e no tênis "Nike" para seus filhos, que na favela quer dizer status. No dia seguinte não têm um tostão e a miséria continua. Não é à toa que entrar no tráfico é a melhor das opções.

Via Internet, pude entrar em contato com outros países onde há pobreza e traçar diagnósticos que fossem comuns a esta população. Posso dizer que em nenhum outro país, com exceção da Colômbia, encontrei a violência urbana nos moldes da cidade do Rio de Janeiro. Com base nestes estudos, ouso dizer que quase a totalidade das crianças com as quais eu lido sofre de doenças mentais diversas, aparentes ou não. Isto não quer dizer que elas sejam insanas, mas que apresentam um quadro de disfunção motora ou de comportamento. Por exemplo, alegria exacerbada, tristeza infinita, perda de apetite, olhos baços, agressividade sem motivo aparente, letargia profunda, falta de concentração e de compreensão. Isto sem esquecer as doenças que são múltiplas e que contribuem para este quadro. A violência do dia a dia faz com que a criança tente proteger-se dentro de um mundo que é só seu, num mundo quase autista.

A escola não está preparada para lidar com esta nova realidade. Nem os professores sabem como agir, nem o currículo é apropriado. Eles não aprendem e, quando chegam à terceira série, quase analfabetos, cansam-se da escola e nunca mais voltam. Começam a trabalhar, vendendo doces ou pe- 
dindo nos sinais, até a entrada definitiva no tráfico. A maioria dos livros escolares contém um vocabulário que lhes é desconhecido. Já estive em várias conferências onde se discutiu a necessidade de se nivelar por cima. Eu discordo. Se a população que freqüenta as escolas públicas brasileiras têm dificuldades de aprendizagem, tem-se de nivelar por baixo. É melhor que aprenda pouco mas que aprenda bem. Os livros são baseados em crianças de classe média, com um bom vocabulário e uma vida mais estruturada. Em vista disto, tive eu mesma de alfabetizar muitas crianças ao longo destes treze anos, com métodos que seriam alvo de processo dentro do Ministério da Educação. Falarei mais deste método no segundo capítulo sobre os meninos de rua.

A violência urbana e a continuação da pobreza está modificando o Brasil e sua mentalidade. Estamos nos tornando mais egoístas, mais fechados, menos abertos a idéias novas, e dando uma guinada perigosa para a direita na política. Pensamos que não, mas a corrupção e a nossa falta de ética atingem principalmente as classes mais pobres. Cada vez menos educa-se para o trabalho, mas para se ganhar dinheiro. E ganhar dinheiro honestamente no Brasil é tarefa bastante difícil. A entrada deles no tráfico de drogas na proporção em que se dá hoje é um fator a considerar, porque o dinheiro ganho com a droga tomou-se uma das únicas opções de vida e de sustento. Nos últimos 10 anos, perdemos mais de 7.000 jovens assassinados pelo tráfico ou pela polícia. Como podemos aceitar este estado de coisas? Mas aceitamos, e o que é pior, uma boa parcela de gente com esta mentalidade neofascista, acha que eles devem mesmo morrer. $O$ medo de assaltos não justifica um assassino em cada um de nós.

Então, vemos o seguinte quadro. De um lado, populações escravizadas pelo narcotráfico e pela polícia, com um quotidiano violento. Do outro, uma sociedade organizada, que cada vez mais odeia preto e pobre começando a mostrar a cara de um Brasil racista. Antes, contanto que ficassem longe da porta da nossa casa, os aturávamos. Agora, não devem mais existir. Na cabeça de uma criança ou de um jovem pobre, qual será a saída? De um lado, fome; do outro, ódio. Teremos de 
equacionar logo este problema, porque já temos uma geração comprometida por este novo status quo. Antes de abordarmos o menino de rua, quero enfatizar que a diferença entre $o$ de favela e o de rua é quase nenhuma, só o local geográfico.

\section{Crianças e jovens na rua}

As crianças e jovens vão viver nas ruas, quando sua capacidade de auto-proteção se esgota. A rua vai representar a liberdade e, num primeiro momento, acredita que será o fim dos seus sofrimentos. A violência da rua é diferente e engloba toda uma movimentação de pessoas num mundo mais colorido que as ruas de terra e o barraco na favela. Quando a criança ou o jovem chega à rua, não sente mais dor física porque sua capacidade de chorar se esgotou. O sexo que ele fazia em casa com adultos vai ser feito entre adolescentes, mais suave, com algum tipo de carinho, como veremos mais adiante.

No título, eu falei de "crianças na rua", propositalmente. Nunca gostei da denominação "criança de rua" porque estas crianças vêm de algum lugar, e estão na rua não por vontade própria, mas sim, porque a vida miserável nas suas casas lhes obrigou a isto.

Antes de começar um trabalho com este segmento devese ter em mente a responsabilidade de estar ali. Porque eles não pediram a nossa presença. Cada um tem os seus motivos para trabalhar com crianças miseráveis: idealismo, vergonha, bondade, etc. Mas o motivo principal deve ser sempre o "amor". Sem ele, não há trabalho educacional que dê certo, seja nas ruas ou nas escolas. Para que se possa começar bem, e adquirir a confiança destas crianças e jovens tão maltratados pela vida, a verdade deve ser absoluta. Verdade sobre sua vida e sobre os propósitos que levam uma pessoa a querer se dedicar a eles: quem é você, o que quer e o que pretende a curto e médio prazo. É neste momento que se sabe se um trabalho é válido ou não. Tem-se também de ter em mente que a paciência vai ter de estar presente em todos os momentos e que, até que a confiança se estabeleça, os dias vão ser povoados de atritos. Na rua, não existe um dia igual ao outro. 
Tudo vai depender do que se passou à noite, do nível da violência do dia, dos dramas de cada um.

Quando comecei a fazer este trabalho, como voluntária, cometi muitos erros. Talvez porque quisesse resultados muito rápidos. Não o da confiança mútua, porque isto ficou estabelecido desde o princípio com cada grupo que trabalhei. Um dos grandes erros foi ter começado um trabalho sem perspectivas de recuperação, ou de profissionalização, ou de desintoxicação destes jovens. Naquela época, todos estávamos engatinhando no problema do menino na rua. Agia-se isoladamente e não havia nenhuma estrutura da parte dos governos. Ninguém sabia nada e todas as instituições que apareceram naquela época, tinham projetos experimentais. $\mathrm{O}$ menino na rua começou a ser conhecido internacionalmente e explorado pela mídia - e muito dinheiro se arrecadou para projetos.

Tudo o que se ensina na rua e só nela, leva muito mais tempo para ser absorvido. Crianças e jovens que nunca tiveram parâmetros de convivência não podem tornar-se bons cidadãos de uma hora para outra. Uma vez que os deixava entregue à sua própria sorte uma boa parte do dia, não podia esperar resultados incríveis. Mas a rua foi uma boa escola e com ela, aprendi a solucionar crises e compreender a vida destas pequenas pessoas com enormes problemas.

O convívio com elas me mostrou que o atendimento tem de ser sempre personalizado. Conhecer a vida de cada um, seus problemas, anseios e amarguras. $\mathrm{O}$ amor, o carinho, $\mathrm{o}$ toque, independente da idade, é primordial para o desenvolvimento das relações. Um rapaz de 17 anos tem as mesmas carências de um de 9, e o fato de se sentar no meu colo e colocar sua cabeça no meu ombro, muitas vezes pela primeira vez, é um gesto de aceitação do trabalho a ser feito. As palavras duras durante o trabalho também são aceitas, desde que qualquer atrito termine com amor. Desta maneira, vão se criando os vínculos que, mesmo depois de adultos, não desaparecem. A pessoa que trabalha com eles tem de desempenhar muitos papéis, agradáveis ou não. $\mathrm{O}$ educador de meninos na rua tem de ter muita sensibilidade para entender e sa- 
ber o momento certo de agir duramente ou não. O que eles esperam de nós é que aquela rua comece a ter cara de casa.

A postura desta pessoa tem que ser impecável porque ela será o espelho na qual elas vão se mirar. Por comportamento exemplar eu quero dizer que o que vai fazer o sucesso do trabalho é a diferença. Nos primórdios do trabalho com meninos de rua, acreditava-se que os educadores deveriam ser parecidos com eles: despenteados, sandália japonesa... Incompreensão. O tempo me demonstrou que deve ser exatamente ao contrário. Uma pessoa bem arrumada, penteada, cheirosa, vai fazer toda a diferença durante o trabalho. Se eu estou mal ajambrada, como vou ter moral para que lavem as mãos ou o rosto antes de o trabalho de rua começar? O que queremos é que eles tenham um comportamento que venha se adequar à sociedade brasileira. Se queremos que saiam da rua e arranjem um emprego, a postura tem que mudar e a sua conscientização do que é o trabalho e coletividade também. Muitos me criticam porque acham que eu quero tirá-los da realidade de suas vidas e torná-los burgueses. A sociedade, burguesa ou não, é organizada e os indivíduos têm de se enquadrar dentro do que existe. Por exemplo, todas as empregadas domésticas são faveladas, mas exigimos que se comportem na nossa casa, dentro dos moldes que nós estipulamos para elas. Com as crianças e os jovens é a mesma coisa, pensar diferente é hipocrisia. Querem tirar um garoto da rua e colocá-lo como boy numa firma. Quero ver alguém conseguir isto sem essa preocupação. Como eles dizem: "é ruim, heim?". Temos que ser obom exemplo humano que eles nunca tiveram a felicidade de conhecer. O estar bem vestido, penteado é muito importante. Elas não querem ninguém que se pareça com elas e vão constantemente examinar e tentar descobrir alguma falha, algum desleixo. Deixar-se conhecer também é primordial. Pouco a pouco, fui levando toda a família para a rua, e esta aproximação da minha realidade tomou o trabalho menos árduo. Normalmente, as instituições não trabalham à noite. Mas é justamente neste período que as coisas ruins acontecem, como no caso da Candelária. É imprescindível que o grupo com o qual se trabalha tenha um telefone SOS à mão. No 
meu caso, era o meu, de casa. Tínhamos um acordo de que entre 11 da noite até às 7 da manhã, o telefone era só para emergências . Nunca os meus grupos descumpriram este acordo. Sempre designava três ou quatro jovens para que me telefonassem durante a noite em caso de emergência. Isto lhes dava um sentimento de responsabilidade com o grupo e comigo. Foi o que aconteceu na noite da Chacina da Candelária. Bocão, de nove anos, correu para o telefone assim que o tiroteio começou.

Nas próximas páginas, vou mais detalhadamente explicar como o meu trabalho foi concebido e quais foram os resultados alcançados. Vou também falar dos abrigos que quase nunca funcionam e da política para o adolescente brasileiro, que é inexistente.

\section{a. Uma casa sem portas nem janelas}

Um dos primeiros problemas que tive de resolver foi o do relacionamento dos grupos com os pedestres e moradores locais. Havia o problema da sujeira, das fezes e urina, das transas ao ar livre, dos gritos e das brigas. A liberdade os toma selvagens e os atritos aconteciam todos os dias. Ficou muito claro para mim que antes de levá-los para qualquer lugar fora dali, tinha de organizá-los numa comunidade. Até para que o meu trabalho fosse aceito.

Depois das primeiras abordagens, que chamei de tempo de "namoro", comecei a aparecer todos os dias. Estipulamos um horário de trabalho que ficou sendo pela manhã. Neste horário, elas estavam com fome e o café com pão e mortadela facilitava as minhas ações.

Era eu quem também limpava a rua de manhã. Chegava com o meu carro, cheio de baldes e desinfetantes. Usávamos a água do mar. Pouco a pouco, os meninos começaram a me ajudar, até que a limpeza tornou-se realmente uma rotina. $\mathrm{O}$ prêmio para toda esta arrumação foi a implantação da escola na rua. E sugeri que se criasse uma escola que eles mesmo denominaram "Posto 6". Durante dias, eu fiquei pensando como começar uma tarefa tão difícil. Quais seriam os parâmetros de ensino e mesmo o que ensinar? A maioria não 
sabia escrever - e foi assim que eu pensei em começar com as aulas sobre cidadania. A condição para começar as aulas era a limpeza da rua. Comprei os cadernos e livros, lápis e borrachas. Elas sabiam que o carro estava com todo o material, mas as aulas não começariam antes da limpeza estar perfeita. Normalmente, quando chegava, a maioria ainda estava dormindo. O despertar tomou-se um ritual. Acordava cada um com carinho e com uma palavra de incentivo ao mesmo tempo que fazia com que o cheiro do pão fresquinho impregnasse o lugar. As manhãs deles começaram a serem engraçadas. Todo este trabalho era feito com muita alegria e a minha eterna disposição ajudava.

No inicio, eu não tinha planos de ação, mas tinha experiência com jovens pobres, adquirida no meu trabalho comunitário em vários países africanos. No fundo, não havia diferença entre o Brasil e a África. Neste nível de pobreza, eram todos excluídos. As idéias surgiam à medida que eu os conhecia melhor. Muitas vezes, elas testavam minha dedicação, telefonando à noite e inventado situações de risco. E eu ia. Nunca faltei ou deixei de atender a um chamado. Aos poucos, as mentiras iam cedendo lugar à confiança, e isto foi primordial para o sucesso do trabalho.

Este primeiro grupo tinha crianças e jovens vindos de diversos lugares do Rio de Janeiro e mesmo de outros Estados. A maioria era de meninas que, na época, tinham em torno de 14 anos. Duas estavam esperando bebê, e isto seria um problema para ser resolvido. Antes de fundarmos a escola, todos os dias tínhamos conversas de todos os tipos: referência familiar, violência, fome, roubo, amor, sexualidade e até a utilidade de eu estar ali com eles. Todas essas conversas eram feitas alegremente, sem pressões ou cobranças. Para se fazer isto, tem de se ter jeito e muito amor pelo próximo.

Aprendi pouco a pouco a aceitar suas vidas amorosas que eram na maioria dos casos, bissexuais. Tive de reciclar minha cabeça para não criticar ou impor o meu modelo de vida, e aprender as diversas maneiras como a sexualidade era apresentada. O lesbianismo, o homossexualismo e o bissexualismo 
aconteciam todos os dias. Só mais tarde, já com muito conhecimento, fui entender todo este mecanismo.

Pouco a pouco, a casa sem portas nem janelas ia tomando corpo, e o verdadeiro trabalho de construção da auto-estima e da cidadania iria começar. Talvez por estarem em Copacabana e receberem muitas informações visuais da classe média e alta, consegui resultados bastante rápidos. O meio ambiente ajudava. Os pedestres e frequientadores da praça começaram a olhar de maneira mais terna para os meninos, e a integração rua/asfalto começou a funcionar melhor. Alguns idosos que ficavam sentados nos bancos começaram a me ajudar durante as aulas, e mesmo os mendigos de outras partes da Copacabana vinham aprender a escrever.

O grupo da Candelária foi mais difícil e tive de readaptar minhas idéias. O centro da cidade é mais árido e as pessoas passam apressadas. Nos fins da semana, não há ninguém, e eles ficam mais largados à própria sorte. Nos grupos longe da zona sul, os chefes são sempre meninos homossexuais, o que demanda um outro tipo de trabalho que analisaremos nos próximos capítulos, quando tratarmos da escola na rua e do problema das drogas.

O que é importante é ter uma dinâmica de trabalho com um tempo muito rápido devido às dificuldades de aprendizado. Isto os leva a uma ocupação constante do tempo em que estamos trabalhando com eles. É esta dinâmica que vai tentar dar uma outra perspectiva às suas vidas, com saídas bastante objetivas.

\section{b. A escola}

A idéia da escola surgiu uns três meses depois que começamos a conviver. E partiu deles a vontade de estudar. A escola na rua não é nenhum ideal de trabalho, mas um instrumento precioso de convivência. Esta escola é muito dinâmica e o aprendizado, simples. Começamos com lápis, papel e desenhos, para todas as idades. Ao mesmo tempo em que descobria jovens talentosos, havia outros que nunca tinham pego num lápis e nem sabiam fechar um círculo. Dividi a turma em dois grupos: os que já tinham passado pela escola, até a 
terceira série, e os que nunca tinham estado num estabelecimento escolar.

Para os completamente analfabetos, de todas as idades, desenvolvi uma cartilha e um livro da caligrafia que começava com linhas retas, sinuosas e círculos. A segunda etapa era fazer desenhos com estas linhas e figuras. Fui aprendendo a reconhecer as dificuldades de cada um e tentava resolvê-las, caso por caso. Esta etapa do processo levou uns 15 dias até manejarem o lápis com alguma destreza. Enquanto isso, os que já tinham uma noção da caligrafia escreviam as vogais e os ditongos. Notei que a grande dificuldade era escrever o $A$ com a perna do lado certo e o $E$ em pé. Isto era uma constante em todos eles, e iria se confirmar quando fossemos escrever o $B, F$ ou $V$ minúsculo. As crianças menores iam mais rápido, e assim, fiz até que os dois grupos ficassem mais ou menos no mesmo nível.

Aprendi rapidamente que o ensino das letras como nós tínhamos aprendido não iria funcionar, porque a concentração deles é muito limitada. A cada 5 minutos, tinha de trocar de tarefa, senão começavam as brigas e as malandragens. Geralmente, eu intercalava com jogos e ginástica. Em vez de aprender e decorar o alfabeto, cada um começou por aprender as letras do seu nome. Costumava dizer que quem não sabe escrever o nome não existe, e que calcar o polegar numa carteira de identidade era vergonhoso para qualquer cidadão. Os nomes brasileiros são enormes, o que me permitiu começar com muitas letras diferentes. Ex.: Pablo João da Silva Maria Jesus. Dispunha estas letras em colunas e, aí sim, decorávamos uma a uma. Isto feito, fazíamos um jogo de palavras. Todos os dias escolhia três nomes.

Fazíamos este jogo com palavras começando pela letra $p$. Quando alguém errava, passávamos para a letra $a$ e assim por diante. Eu fazia com que esta brincadeira se tornasse bem divertida, e eles apreendiam mais rápido do que com o método tradicional.

Não foi fácil com tantas crianças e jovens, mas funcionou. A escola tomou-se uma rotina na rua e eles passaram a fazer disto uma parte de suas vidas. Quando achei que o alfa- 
beto estava memorizado, começamos a escrever. Esta foi a tarefa mais difícil, porque parecia que havia um muro que barrava a conexão entre escrita e leitura. Anos depois, trabalhando com crianças faveladas, quase indigentes, constatei que alunos freqüentando a terceira série não sabiam ler.

Como seu vocabulário era muito restrito, os livros de leitura existentes eram, na sua maioria, incompreensíveis. Desta maneira, começamos a escrever e ler as palavras que diziam todos os dias e todas as horas. Não me importava que fosse um palavrão como "puta" ou "merda". A partir da palavra "puta", falávamos da mulher, da reprodução. Com "merda", estudamos o corpo humano, suas secreções, mastigação. Tudo servia para aprender e discutir. Era uma adaptação do método Paulo Freire para o asfalto.

$\mathrm{O}$ meu maior interesse era que aprendessem a escrever razoavelmente para que pudéssemos fazer redações, e para que, finalmente, pudessem pôr suas emoções no papel, sem ter vergonha de falar, como verão nas páginas que completam este trabalho. Recortava assuntos dos jornais relativos à cidade e ao país para que pudessem se informar. Com o tempo, discutíamos estes assuntos e escrevíamos sobre eles. Foram as primeiras lições da cidadania. Entender como funciona uma cidade e para que servem os impostos. Isto foi muito importante para que respeitassem o gari que limpava aquela área e não debochassem dele e do seu trabalho. Aprender o ECA, discuti-lo, mas principalmente estar ciente dos seus deveres como cidadãos. Este intercâmbio começou a funcionar, um ano depois que a escola foi fundada. Quando as pessoas paravam para ver o trabalho, sempre pedia que falassem de suas vidas, dos seus empregos. Este intercâmbio com eles abriu muito suas mentes e baixou de uma maneira incrível o nível de agressividade entre eles.

Com o tempo, comecei a levar textos de livros para discutirmos e, uma certa vez, li para os mais velhos, a "Metamorfose" de Kafka. Mostraram grande interesse e a história da barata serviu para inúmeras outras histórias que aí foram inventadas. Para os mais pequenos, criei uma "Série Cidadania", que brevemente será publicada, com ilustrações feitas por eles. 
Não existe sucesso sem trabalho árduo, só no dicionário. Passava com eles cinco horas do meu dia, desde o café da manhã até a hora do almoço. Pouco a pouco, segundo os interesses, fundamos cooperativas e até um banco como veremos no capítulo a seguir.

\section{c. O Trabalho}

A falta de uma educação voltada pala o trabalho leva à uma evasão escolar ou à entrada dos jovens nas gangues, na violência e no tráfico de drogas que, este sim, os profissionaliza no mundo do crime. O que eu tentei ensinar a estes meninos e meninas é que o trabalho não é somente uma maneira de se ganhar a vida. Significa também, ter uma conduta, ter uma disciplina de vida. Um emprego regular determina o ir e vir de uma pessoa. $\mathrm{Na}$ ausência desta regularidade, a vida e mesmo a família deterioram-se. Como fazer com que crianças e jovens, excluídos, pudessem ter uma rotina? A limpeza da rua e a escola foram um primeiro passo, mas não era o suficiente, porque não gerava renda.

Começamos com uma cooperativa de cadeiras de praia para crianças, com dez meninos. Eu financiei o material, armação e plástico, e eles encordavam. Um outro grupo catava latas. Outro, vendia doce, lavava carros ou vendia sorvete na praia. Outros engraxavam sapatos. As caixas de sapateiro, fazíamos ali mesmo na rua. Os maiores ensinavam aos menores. Eu só financiava a primeira mercadoria. Depois, tinham de se virar sozinhos. Isto, na rua, não foi fácil. O primeiro mês foi um fracasso, porque não tinha me dado conta da que não sabiam o quanto valiam as coisas que vendiam. Simples matemática. Fiz para eles uma espécie de tabela para que entendessem:

$\begin{array}{ll}\text { - custo } & \text { - compra de novo material } \\ \text { - pre de venda } & \text { - lucro }\end{array}$

Quando entenderam a questão do lucro, cada um tinha um envelope guardado comigo. De cada cinco reais que faziam, um real vinha para o envelope, numa espécie de poupança. A experiência foi muito válida, mas tendo sido feita na 
rua, dispersava-se muito, porque sempre há muita rotatividade nos grupos. Bastava um deles ser preso ou morrer que o processo ficava interrompido. Mas eu tenho certeza de que este aprendizado ficou para sempre. Como no caso do Fábio, menino da Candelária que engraxava sapatos no Centro da cidade, e hoje é compositor de samba, e ganhador de samba-enredo da escola de samba "Estácio de Sá". Muitos aprumaram, muitos morreram, muitos entraram para a marginalidade, mas as cartas que me escrevem até hoje, dos empregos ou das prisões, mostram que aquele tempo foi feliz, e que eles nunca se esqueceram.

Recentemente, tive uma experiência muito feliz com um curso profissionalizante que montei para meninos de rua no ramo da hotelaria. Foi um sucesso e, em dois meses, aprenderam a ser ajudantes de doceiro. Dos 5 primeiros, 2 estão empregados e 3 foram aceitos no SENAC. Uma vitória. Este projeto vai ser ampliado em 1997 para que mais jovens possam participar.

\section{d. Tráfico de drogas e a polícia}

Os meninos de rua e a polícia estão em atrito constante. Dez anos atrás, poucos policiais conheciam o ECA e não aceitavam esta nova maneira de pensar. Hoje, esta relação mudou um pouco; com um maior conhecimento dos policiais, com a implantação dos conselhos tutelares e com mais atenção da prefeitura para o problema. Nenhum menino na rua é anjo e todos cometem delitos, desde furtos até uso de drogas. Infelizmente, a polícia não é nenhum exemplo de virtude e, muitas vezes, denunciei policiais que mandavam os meninos roubar para dividir o produto do roubo. Isto dificultava e dificulta a relação com autoridade. Os mais velhos podem até vender a droga, escondendo-se atrás dos menores. O tráfico de drogas faz-se presente em toda a cidade. Mesmo em todos os quarteirões da orla. Nas sextas-feiras, quase todos sobem os morros para ir aos bailes e, como é natural, fumam maconha ou cheiram cocaína. Na rua, o começo é sempre com a cola. Esta é a parte mais difícil do trabalho. A condição para eu 
estar com eles era, desde o momento da minha chegada, esconderem as latas de cola ou qualquer droga. Se não o fizessem, eu ia embora. E nisto eu era firme! Seria incongruente, trabalhar com eles e permitir que se drogassem. Naquela época, não havia nenhuma clínica de desintoxicação para jovens e crianças pobres. Desde dois meses, funciona uma em Vila Isabel que atende cerca de 30 crianças e jovens. Já é um começo. Outra regra que implantei na rua dizia respeito ao envolvimento com traficantes. Se algum deles fosse baleado em guerra de tráfico ou coisas do gênero, não podia contar comigo. Eu sempre dizia que não era palhaça e nem idiota. Eles riam, mas entendiam. Ao mesmo tempo que me amavam, tinham respeito e um certo medo de mim. Mesmo quando me odiavam. Muitas vezes, dependendo do que acontecia de noite, era apedrejada quando chegava pela manhã. Eu não me importava porque sabia que o amor e o ódio estavam muito próximos um do outro naqueles corações. Agüentava firme, mas não esmorecia na implantação das regras. Tentava ser justa. Se a polícia batia, eu brigava. Quando eles tinham medo de noite, chamavam-me e eu dormia na rua com eles. Tudo isto foi criando uma confiança recíproca. Não tolerava mentiras nem invenções. Por isso, quando dizem que os meninos da Candelária mentiram quando reconheceram os PMs assassinos, eu defendo que não é verdade. Não nos grupos com os quais eu trabalho. Se não existe verdade, não existe recuperação.

Hoje, eu tenho consciência de que, se naquela época, eu tivesse tido um espaço ou uma organização, o trabalho renderia mil vezes mais. Depois da chacina da Candelária, quase não existem grupos trabalhando na rua, só as Igrejas, que têm uma proposta caritativa e evangelizadora. Ainda bem que eles existem, senão os meninos de rua estariam completamente abandonados.

\section{e. Sexualidade}

A maioria dos meninos e meninas de rua praticam a bissexualidade, e ela não deve ser contestada. Na rua existem mais meninos que meninas, e a relação homossexual é nor- 
mal. Isto não quer dizer, necessariamente, que eles serão homossexuais mais tarde. O lesbianismo também é bastante comum, e se acentua à medida que elas vão sendo presas nos reformatórios e, mais tarde, nas prisões. Fazer sexo é o único lazer. As relações não são duradouras, mesmo se a menina tem um filho. A paternidade não tem nenhuma importância. Às vezes, grávidas de um, elas já estão com outros. Ter regras de conduta neste campo é absolutamente impossível se eles estão na rua. Nenhum educador passa 24 horas com eles - e quem somos nós para julgar?

Porém, a educação sexual faz-se necessária, não como princípio repressor, mas sim com objetivos de esclarecimento, fazer com que eles se sintam responsáveis pelos seus corpos, para que não os maltratem. É este esclarecimento constante que vai fazer com que um dia, peçam para tomar pílula ou colocar uma camisinha. Não se pode impor. Se o fizermos, estaremos destinados a fracassar. O mesmo se passa com a maternidade precoce. Já é difícil criar um filho, imaginem se a mãe tiver 12 anos.

Com o tempo, adquiri a convicção de que o planejamento familiar é necessário e em vez delas irem ao encontro dele, nós temos de chegar a elas. Não adianta querer que uma menina pobre vá ao posto. Ela não vai. $\mathrm{O}$ atendimento tem de ser volante. O conhecimento do corpo é indispensável para que a vontade de planejar se manifeste. Para elas, a concepção não é um ato de amor. Todas querem ter filhos desde muito jovens; dizem sempre que a criança será a única coisa que possuem. Uma coisa só delas. Se eu reclamava que a criança estava suja ou coisa parecida, a resposta vinha rápida: “A senhora não tem nada com isso. Se eu quiser bater eu bato, se quiser matar, eu mato."

O pior é que, muitas vezes, a falta de cuidados com os bebês acaba terminando em óbito. Isto aconteceu muitas vezes sem que eu pudesse evitar.

O ensino sobre educação sexual baseava-se unicamente em conhecimento do corpo; concepção; reconhecimento de doenças venéreas (sífilis, gonorréia e cancro); prevenção so- 
bre AIDS, com ampla documentação e comportamento em locais públicos.

Não era um ensinamento moral, porque naquele estado de degradação, seria quase impossível estabelecer regras éticas de comportamento sexual. Isto viria depois com o tempo e a assimilação do aprendizado. Muitas vezes, eram os próprios meninos e meninas que desenhavam sua vida sexual ilustrando as aulas. Os desenhos provocavam muitos risos e brincadeiras, o que facilitava o diálogo.

No que diz respeito ao tráfico de drogas e a traficantes, eu era e sou bem específica sobre os perigos de entrar para o tráfico. Mas enquanto eu não tive uma alternativa de vida para oferecer, não fui e não sou bem sucedida. O curso "meninos de rua" na hotelaria despertou a vontade de trabalhar em muitos meninos que ouviram falar do curso e que queriam sair da rua. O mesmo acontece com instituições que atendem jovens pobres, que me telefonam todos os dias. Acho que aí está o mapa da mina. Durante o último curso, todas estas questões foram discutidas com os alunos e a diferença de comportamento logo na primeira semana foi incrível. Mas, para isto, temos de ter educadores bem trabalhados e especificamente treinados para este trabalho. O tempo dos "curiosos" acabou. Já temos no Brasil um know-how muito grande deste segmento da população, e chegou a hora de empregar estes conhecimentos em projetos práticos e de ação bastante rápida. A situação da delinqüência juvenil está fora de controle e a ociosidade dos jovens os empurra para a marginalidade. No ano passado, a quantidade de crimes de assassinato cometidos por adolescentes de 11 a 17 anos triplicou e não podemos deixar a situação deteriorar ainda mais. O menino na rua é o retrato vivo deste descaso. Mas antes de chegarem às ruas, constituem um exército de milhões de crianças brasileiras sem futuro. O que se pede de todos que se interessem por este segmento é trabalho duro, educativo e com soluções criativas. Só assim construiremos nosso futuro.

\section{Casos especificos}

a. Amanda tinha 9 anos quando teve pai e mãe mortos por traficantes. No dia em que sua mãe levou um tiro na cabeça, 
ela não mostrou nenhuma emoção. Quando cheguei para trabalhar, ela me levou ao local do crime e sua ênfase foi na trajetória da bala que tinha varado um olho. Logo depois, Amanda começou a viver em diversas casas dentro da favela. Sua agressividade aumentou barbaramente. Sem referência nenhuma, começou a se prostituir no centro da cidade. Hoje tem dez anos e está completamente estragada no seu íntimo. Não consegue freqüentar uma escola, não consegue aprender.

b. Josenilson tem 10 anos. Mãe bêbada, não conhece o pai, irmã de 14 anos prostituta, um irmão doente e vivendo em condições sub-humanas. Sua agressividade apareceu muito cedo e não consegue se comunicar a não ser por socos e pontapés. É o primeiro a chutar um cadáver e, com nove anos, já era "avião da droga", consumindo maconha. Roubou um traficante e foi punido três vezes: com um fio desencapado, foi amarrado num formigueiro e teve um braço quebrado. Além de apanhar do traficante, apanhava em casa. Suas mãos tremem, nenhuma concentração, não consegue falar direito e não é articulado.

c. Carlos, 10 anos. Mãe alcoólatra, não conhece o pai. Vive com a mãe e com um irmão homossexual. Desde pequeno participa da vida sexual em casa. Já apresenta sinais de homossexualismo. Por diversas vezes teve que ser levado ao hospital com fissura no ânus. Muito inteligente e rápido. Apesar disso, não consegue freqüentar uma escola. E inquieto, agressivo e não tem concentração.

d. Lilica, 10 anos, uma de dez filhos. Não vai à escola; muito inteligente, mas com grandes dificuldades de aprendizagem e de concentração. Vive no mundo da fantasia. Inventa histórias rocambolescas e acha que é sua realidade.

e. Everton, 4 anos, não conhece o pai. Apanha desde pequeno e recolheu-se em seu mundo interior. Às vezes, consigo estabelecer algum contato, mas ele é rápido e logo se volta para dentro. Começa a querer falar, mas não consegue. Está sempre triste, não ri nunca.

f. Felipe, 6 anos, não conhece o pai. Foi estuprado aos quatro anos e, desde então, não consegue nem brincar. Bate o tempo todo e sua concentração é zero. 
Estes são exemplos representativos de milhões de crianças brasileiras que estamos condenando. Serão adultos problemáticos e nunca conseguirão chegar a um equilíbrio, se não se fizer alguma coisa. Este é o meu trabalho, um trabalho de construção difícil e mal compreendido. Talvez eu não consiga ver a mudança que eu gostaria de ver acontecer no Brasil. Mas eu quero ser uma pequena parte deste processo. Não viver só olhando para o meu próprio umbigo, num país que precisa do trabalho e do amor de todos nós.

Yvonne Bezerra de Mello é formada em Letras e Lingüística e Línguas Escandinavas, pela Universidade de Paris III (Sorbonne). Além disso, realizou diversos cursos em Ciências Politicas, Linguas e Artes na Itália, Suécia, França, Portugal e Brasil. Seus trabalhos sociais em Angola, Tanzânia, Quênia, Cabo Verde, Portugal e, principalmente, no Brasil, foram reconhecidos internacionalmente com diversos prêmios, entre eles, a indicação pela ONU como uma das 45 mulheres que contribuiram para a melhoria da humanidade em 1995 e o "Femme Lumière", concedido pela UNESCO em 1997. Endereço para correspondência: Av. Rui Barbosa, 566/1061, 22450-020, Rio de Janeiro, RJ.E-mail:yvonne@mtec.com.br. 